\title{
Influence of Electronic Conducting Additives on Cycle Performance of Garnet-based Solid Lithium Batteries
}

\author{
DU Fu-Ming ${ }^{1,2}$, ZHAO Ning ${ }^{3}$, FANG Rui ${ }^{1,2}$, CUI Zhong-Hui ${ }^{1}$, LI Yi-Qiu ${ }^{1}$, GUO Xiang-Xin ${ }^{1}$
}

(1. State Key Laboratory of High Performance Ceramics and Superfine Microstructure, Shanghai Institute of Ceramics, Chinese Academy of Sciences, Shanghai 200050, China; 2. University of Chinese Academy of Sciences, Beijing 100049, China; 3. College of Physics, Qingdao University, Qingdao 266071, China)

\begin{abstract}
Solid state lithium batteries based on garnet-type solid electrolytes face the problem of contact between the solid electrolytes and the solid cathodes, which deteriorates the cycle performance. Aiming to overcome such problem, the solid state batteries with the $\mathrm{LiNi}_{1 / 3} \mathrm{Co}_{1 / 3} \mathrm{Mn}_{1 / 3} \mathrm{O}_{2}$-based cathodes, the $\mathrm{Li}_{6.4} \mathrm{La}_{3} \mathrm{Zr}_{1.4} \mathrm{Ta}_{0.6} \mathrm{O}_{12}$ ceramic electrolytes, and the lithium metal anodes were studied. For constructing the $\mathrm{LiNi}_{1 / 3} \mathrm{Co}_{1 / 3} \mathrm{Mn}_{1 / 3} \mathrm{O}_{2}$-based composite cathodes, three-kind carbons were used as electronic conducting additives. It is found that the batteries with cathodes containing vapor grown carbon fibers (VGCFs) show better cycle performance than those with granular Ketjen Black as well as Super P carbons. Analysis indicates that the VGCFs result in less side reaction at high charge potential than do other two electronic additives, leading to reduced carbonates that cause the increase of the internal cell resistance. These results suggest that stability of electronic additives has important influence on cycle performance of solid state lithium batteries.
\end{abstract}

Key words: solid state lithium batteries; interfacial resistance; garnet electrolytes; lithium anodes; composite cathodes

The rapid development of electric vehicles (EVs) demands greatly improved safety and energy-density prospect for the lithium ion batteries. Solid state lithium batteries (SSLBs) are considered as one of the most promising alternatives ${ }^{[1-4]}$. By substituting the combustible organic liquid electrolytes with the solid electrolytes, SSLBs not only can be densely packed but also allow incorporation of lithium metal anode and high voltage cathodes, providing possibility to gain the high volumetric as well as the gravimetric energy densities ${ }^{[5-6]}$. Under such circumstance, the garnet-type solid electrolyte, $\mathrm{Li}_{7} \mathrm{La}_{3} \mathrm{Zr}_{2} \mathrm{O}_{12}$ (LLZO) has attracted attention because of its high lithium ion conductivity ( $\geqslant 10^{-4} \mathrm{~S} / \mathrm{cm}$ at room temperature), a wide electrochemical window (above $6 \mathrm{~V}$ vs. Li/ $\mathrm{Li}^{+}$), and chemical stability against the lithium metal ${ }^{[7-13]}$.

As the LLZO is used in the SSLBs, two crucial issues need to be concerned. One is to further improve the ionic conductivity of LLZO ceramic. With optimization of element substitution (e.g. $\mathrm{Al}$, $\mathrm{Ta}$ or $\mathrm{Nb}$ ) and sintering process (e.g. hot-pressing sintering), ionic conductivity of Ta-doped LLZO (LLZTO) can be as high as $1.6 \times 10^{-3} \mathrm{~S} / \mathrm{cm}$ at $25^{\circ} \mathrm{C}$, which approaches the maximum level regarding LLZO-based electrolytes $^{[8-11]}$. The other one is to solve the problem of resistive contact between the electrode and the solid electrolyte, which plays a critical role in the cycle performance ${ }^{[12]}$. For the Li metal/LLZO interfaces, there are useful approaches including polishing, coating, and microstructure controlling of the LLZO surface to reduce the $\mathrm{Li} / \mathrm{LLZO}$ interfacial impedance ${ }^{[13-15]}$. For the cathode/LLZO interfaces, it is necessary to construct electronic as well as ionic networks on the cathode side for bulk-type solid state lithium batteries. Through the sintering technique, composite cathodes consisting of active electrodes (e.g. $\mathrm{LiCoO}_{2}$ ) combined with $\mathrm{Li}^{+}$or/and $\mathrm{e}^{-}$conducting particles (e.g. LLZTO, $\mathrm{LiBO}_{3}, \mathrm{In}_{2} \mathrm{O}_{5} \mathrm{Sn}$ ) were sintered together with the LLZTO powder electrolytes at $700-900^{\circ} \mathrm{C}$, aming to gain good ionic and electronic conducting networks in the composite cathodes as well as closely connected electrolyte/cathode interfaces ${ }^{[16-18]}$. Nevertheless, the used temperature range (i.e. below $900^{\circ} \mathrm{C}$ ) on one hand was difficult to fabricate dense and thus highly conducting electrolyte layers, on the other hand

Received date: 2017-04-12; Modified date: 2017-05-17

Foundation item: National Natural Science Foundation of China (51532002, 51402339); National Basic Research Program of China (2014CB921004); Strategic Priority Research Program of Chinese Academy of Science (XDA09010202); Natural Science Foundation of Shanghai (17ZR1434600)

Biography: Du Fu-Ming(1989-), male, candidate of PhD. E-mail: dufuming@student.sic.ac.cn

Corresponding author: GUO Xiang-Xin, professor. E-mail: xxguo@mail.sic.ac.cn 
was unfortunately to cause phase transition of crystalline cathodes and/or reactions between the cathodes and the electrolytes ${ }^{[19-20]}$. To overcome such problem, it was suggested that combination of sufficiently high-temperature sintered ceramic electrolytes with low-temperature processed electrolyte/cathode interfaces should be beneficial to achieve good conducting electrolyte layers as well as various interfaces in SSLBs ${ }^{[21]}$. This idea proved to be a good means in our previous research, with the composite cathodes made of $\mathrm{LiFePO}_{4}: \mathrm{KB}: \mathrm{PVdF}: \mathrm{LiTFSI}$, which were coated on high-temperature sintered LLZTO ceramic plates, the SSLBs show good cycle and rate performance at $60^{\circ} \mathrm{C}$ and $100^{\circ} \mathrm{C}^{[22]}$. Nevertheless, such interfacial issue for the $\mathrm{LiNi}_{1 / 3} \mathrm{Co}_{1 / 3} \mathrm{Mn}_{1 / 3} \mathrm{O}_{2}$-based cathode that works in the larger voltage range than the $\mathrm{LiFePO}_{4}$ based one has been seldom discussed previously.

Therefore, in this work, we carry out study on the solid state batteries composed of Li metal anodes, LLZTO ceramic electrolytes and $\mathrm{LiNi}_{1 / 3} \mathrm{Co}_{1 / 3} \mathrm{Mn}_{1 / 3} \mathrm{O}_{2}$ (NCM)-based composite cathodes. NCM is used to replace $\mathrm{LiFePO}_{4}$, which shows specific capacity of $150 \mathrm{mAh} / \mathrm{g}$ in the voltage range of $2.8-4.3 \mathrm{~V}$ and $200 \mathrm{mAh} / \mathrm{g}$ in the range of 2.8-4.6 $\mathrm{V}^{[23-24]}$. Theoretical calculations indicated that the carbon additives may react with the $\mathrm{Li}^{+}$conducting additives at high voltage ${ }^{[25-26]}$. This point has been paid attention here. It is found that except for key influence of the $\mathrm{Li}^{+}$conducting additives on the cycling performance, the $\mathrm{e}^{-}$conducting additives especially their stability at the high voltage are critical to the cycle life of SSLBs.

\section{Experimental}

\subsection{Fabrication of composite cathodes, car- bon electrodes, and solid state batteries}

Composite cathodes consisted of poly(vinylidene fluoride) (PVdF) (Alfa Aesar), $\mathrm{Li}\left(\mathrm{CF}_{3} \mathrm{SO}_{2}\right)_{2} \mathrm{~N}$ (LiTFSI) (99.95\%, Sigma-Aldrich), $\mathrm{LiNi}_{1 / 3} \mathrm{Co}_{1 / 3} \mathrm{Mn}_{1 / 3} \mathrm{O}_{2}$ (NCM), and one of the following carbon additives: Ketjen Black (KB), Super P (SP), or vapor grown carbon fiber (VGCF), which are denoted as NCM-KB, NCM-SP, NCM-VGCF, respectively. The $\mathrm{PVdF}$ polymers were dissolved in $N$-methyl-2 pyrrolidon (NMP) and stirred for $24 \mathrm{~h}$, which were followed by addition of LiTFSI, NCM, and carbon in an agate mortar and ground for $1 \mathrm{~h}$. The obtained slurries were coated on one side of each LLZTO ceramic plate with the diameter of $1 \mathrm{~cm}$ and the thickness of $0.1 \mathrm{~cm}$ by blades (Detailed description of preparation process and characterization of $\mathrm{Li}_{6.4} \mathrm{La}_{3} \mathrm{Zr}_{1.4} \mathrm{Ta}_{0.6} \mathrm{O}_{12}$ (LLZTO) ceramics can be found in our previous work ${ }^{[22]}$ ), then dried in an oven at $80^{\circ} \mathrm{C}$ for $2 \mathrm{~h}$ to remove NMP. After being pressed with stainless-steel plate, the cathodes were dried in a vacuum oven at $80^{\circ} \mathrm{C}$ again for $12 \mathrm{~h}$ to remove the trace amount of NMP and moisture. The typical mass of each cathode was $1.5-2.5 \mathrm{mg} / \mathrm{cm}^{2}$. The weight ratio between NCM, LiTFSI, carbon, PVdF was fixed at 50 : $35: 10: 5$ according to the optimum ratio ${ }^{[22]}$. Carbon electrodes excluding NCM were also fabricated in the same manner except that they were only made up of carbon, PVdF, and LiTFSI. Then, Li anodes were attached on the other side of each LLZTO by high pressure in an Ar-filled glove box with oxygen and moisture levels below $0.1 \times 10^{-6}$. Finally, each laminated solid state battery was assembled in a Swagelok-type cell. The stainless steel (SS) foils instead of Al were chosen as current collectors in order to avoid the reaction between thet al and LiTFSI.

\subsection{Electrochemical measurements}

Galvanostatic charge and discharge behaviors of the NCM-based cathode/LLZTO/Li batteries were investigated using an Arbin BT-2000 battery tester with the potential ranging from $4.3 \mathrm{~V}$ to $2.8 \mathrm{~V}$ at $60^{\circ} \mathrm{C}$. The current density and capacity were normalized to the mass of NCM, i.e. $0.1 C$ rate being $15 \mathrm{~mA} / \mathrm{g}$. Linear scan voltammetry (LSV) with respect to the different carbon electrodes/LLZTO/Li cells was measured on an electrochemical workstation (Autolab) between $2.8 \mathrm{~V}$ and $4.3 \mathrm{~V}$ at a scan rate of $0.1 \mathrm{mV} / \mathrm{s}$ and $60^{\circ} \mathrm{C}$. Galvanostatic charge behaviors of carbon electrodes/LLZTO/Li cells weret also investigated using an Arbin BT-2000 battery tester with the potential ranging from $4.3 \mathrm{~V}$ to $2.8 \mathrm{~V}$ at $60^{\circ} \mathrm{C}$, but the current density and capacity were normalized to the mass of carbon materials. Electrochemical impedance spectroscopy (EIS) measurements were performed in a frequency range of $1 \mathrm{MHz}$ to $0.1 \mathrm{~Hz}$ with an amplitude of $10 \mathrm{mV}$ using an Autolab instrument at $60^{\circ} \mathrm{C}$. Beforet all the above tests, the batteries/cells were firstly rested in a thermostatic oven for $6 \mathrm{~h}$ to reach $60^{\circ} \mathrm{C}$.

\subsection{Characterization}

Cross-section and surface morphologies and elements analyses of the solid state batteries were tested by scanning electron microscopy (SEM, SU8220) with energy dispersive spectrometer (EDS). X-ray photoelectron spectroscopy (XPS) of carbon cathodes were carried out by ESCAlab-250 with an $\mathrm{Al}$ anode source. The samples were pre-sputtered at a pressure of $3 \times 10^{-9} \mathrm{~Pa}$. For the above measurements, the samples during transfer were carefully protected with Ar atmosphere without exposing to ambient air.

\section{Results and Discussion}

\subsection{Microstructures of solid state lithium batteries}

Figure 1(a) and (b) show typical cross-section and plane view of SEM for solid state lithium batteries with 
VGCF as the electronic additive. The NCM composite cathode and LLZTO ceramic plate closely connected and the thickness of NCM composite cathode is approximately $10 \mu \mathrm{m}$, as shown in Fig. 1(a). The NCM composite cathode is made up of NCM, VGCF, PVdF, and LiTFSI, which are well distributed in the cathode, as can be distinguished from Fig. 1(b) and the EDS mapping of $\mathrm{C}$ (mainly from VGCF) and S (from LiTFSI) elements in Fig. 1(c) and (d).

\subsection{Effects of electronic additives on electroc- hemical performance}

Besides necessary of the ionic conducting additives in NCM-based solid state lithium batteries (shown from Fig. S1), it is worth mentioning that the introduction of electronic conducting additives is also needed for the cycling solid state battery. As can be seen in Fig. 2(a) and Fig. 2(b), the solid state battery excluding the electronic conducting additive shows only $10 \mathrm{mAh} / \mathrm{g}$ for the first charge capacity and $9 \mathrm{mAh} / \mathrm{g}$ for the first discharge capacity. Whereas the one with $\mathrm{KB}$ as the electronic conducting additive shows $242 \mathrm{mAh} / \mathrm{g}$ for the first charge capacity and $126 \mathrm{mAh} / \mathrm{g}$ for the first discharge capacity. This is clearly indicated that the solid state battery cannot work properly without the electronic conducting additives.

Moreover, it is further found that different carbon
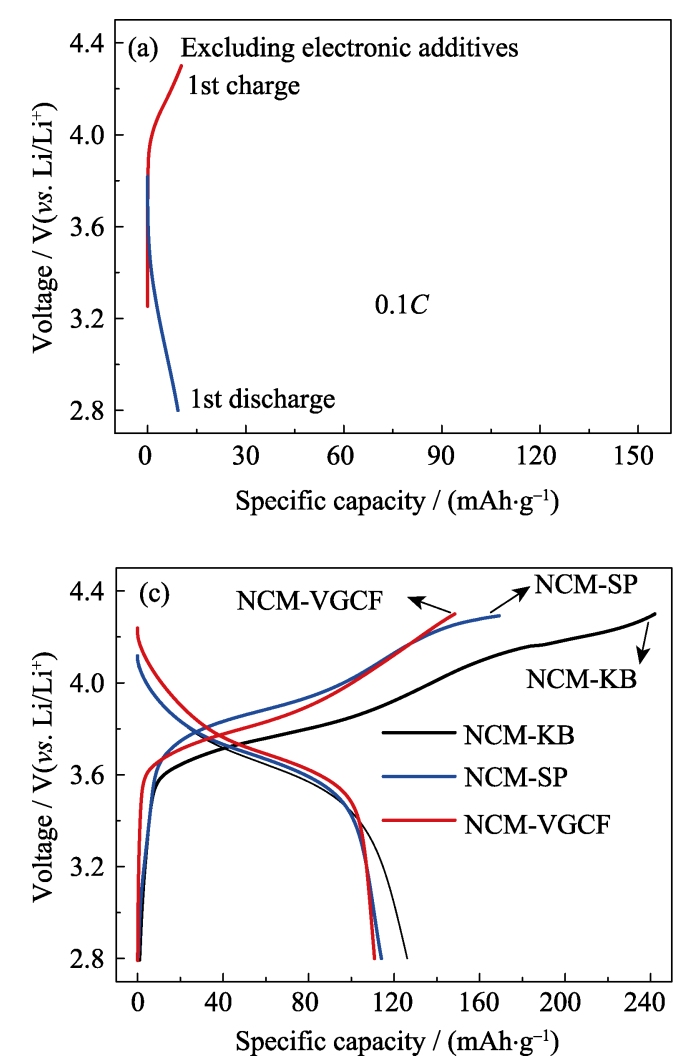

additives in the NCM-based composite cathodes have significantly different influence on the cycle performance of the solid state batteries. As shown in Fig. 2(c) that gives the electrochemical performance of NCM-based cathode/LLZTO/Li batteries with different carbon additives for the $1^{\text {st }}$ charge-discharge profiles, the initial charge capacity of $242 \mathrm{mAh} / \mathrm{g}$ with respect to the NCM-KB composite cathode is far greater than that for the NCM-SP (i.e. $186 \mathrm{mAh} / \mathrm{g}$ ) or NCM-VGCF (i.e. $148 \mathrm{mAh} / \mathrm{g}$ ) cathode. Concerning the theoretical capacity of NCM at $4.3 \mathrm{~V}$ should be $150 \mathrm{mAh} / \mathrm{g}$, it is obvious that the side reactions
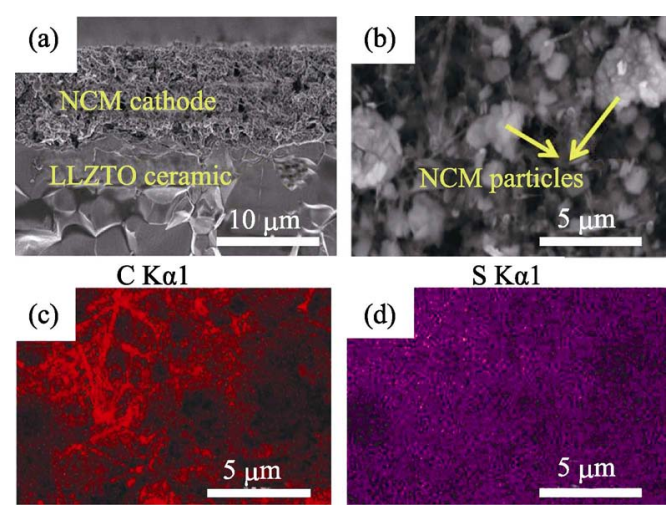

Fig. 1 (a) Cross-section and (b) plane view SEM images of NCM- based solid state lithium batteries, (c) and (d) EDS mapping of $\mathrm{C}$ and $\mathrm{S}$ elements in (b), respectively
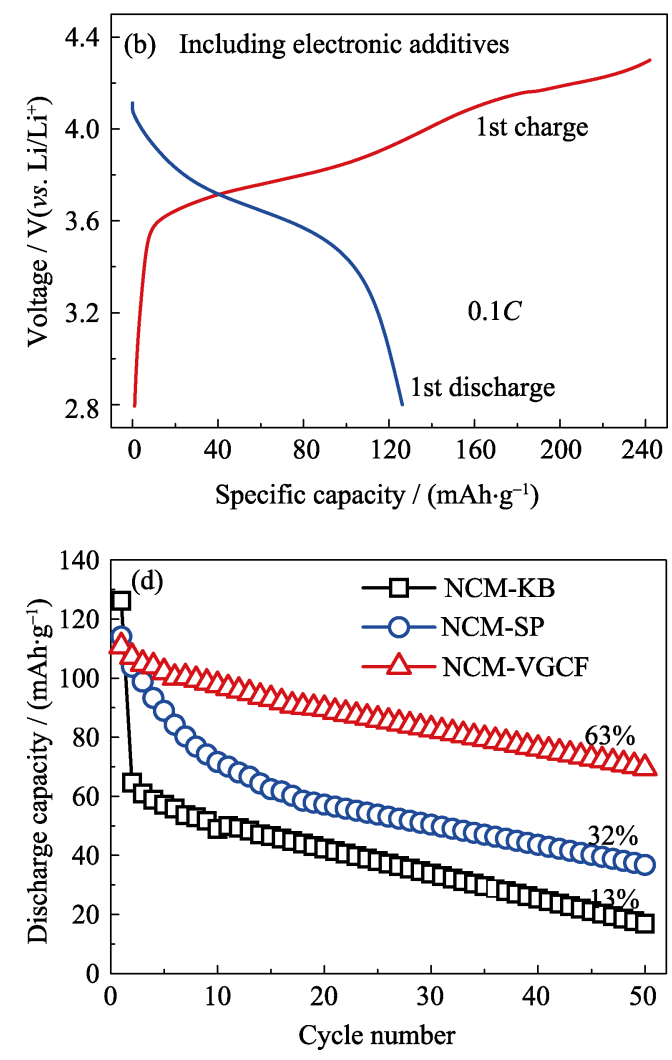

Fig. 2 The $1^{\text {st }}$ charge-discharge profiles of NCM-based cathode/LLZTO/Li batteries with the composite cathodes (a) excluding and (b) including electronic additives (KB); (c) Comparison of NCM-based solid state batteries with different carbon additives for the $1^{\text {st }}$ charge-discharge profiles and (d) the discharge capacity as a function of cycle number 
occur as the voltage above $4 \mathrm{~V}$ during the first charge. As a result, concerning the initial Columbic efficiency of NCM-based cathode/LLZTO/Li batteries with the NCM-KB, NCM-SP, and NCM-VGCF exhibit the values of $52 \%, 61 \%$, and $74 \%$, respectively, the NCM-KB cathodes should have the side reactions in the largest degree and the NCM-VGCF counterparts do in the smallest degree. Fig. 2(d) shows the discharge capacity as a function of cycle number for the three-kind composite cathodes. It can be seen that the discharge capacity of NCM-KB composite cathodes fades in the fastest way. From the $1^{\text {st }}$ to the $2^{\text {nd }}$ cycle, nearly $50 \%$ of the discharge discharge capacity (i.e from 126 to $65 \mathrm{mAh} / \mathrm{g}$ ) is lost. Only $13 \%$ capacity retains after 50 cycles. In contrast, from the $1^{\text {st }}$ to the $2^{\text {nd }}$ cycle, the capacity decreases by $11 \mathrm{mAh} / \mathrm{g}$ (114 to $103 \mathrm{mAh} / \mathrm{g}$ ) for the NCM-SP batteries and $3 \mathrm{mAh} / \mathrm{g}$ (110 to $107 \mathrm{mAh} / \mathrm{g}$ ) for the NCM-VGCF batteries. After 50 cycles, the NCM-SP and the NCM-VGCF composite cathodes show show the capacity retention of $32 \%$ and $63 \%$, respectively. Taking into account the $\mathrm{Li}^{+}$source is in excess in all of the NCM-based cathode/LLZTO/Li batteries and the same used active material (i.e. NCM), the reason for the cycle difference should be attributed to the side reactions occurred at the cathode side, which continuously forms resistive passivation layers. This is supported by the following impedance spectroscopy analysis. The formed products hinder the $\mathrm{Li}^{+}$migration across the cathode/electrolyte interface as well as worsen the electrical contact between the active material and the electronic additives, consequently deteriorating the overall cycle performance.

\subsection{Analysis of electrochemical impedance spectroscopy}

Electrochemical impedance spectroscopy (EIS) of the pristine batteries and those after the $1^{\text {st }}$ charging to $4.3 \mathrm{~V}$ and the $50^{\text {th }}$ cycle are measured and shown in Fig. 3(a)-(c). For the pristine batteries, the overall internal resistance is nearly the same for the three ones (i.e. approximately $2 \mathrm{k} \Omega$ ). After the $1^{\text {st }}$ charging to $4.3 \mathrm{~V}$, such value increases to $6.5 \mathrm{k} \Omega$ for the NCM-KB, $4.3 \mathrm{k} \Omega$ for the NCM-SP, and $2.6 \mathrm{k} \Omega$ for the NCM-VGCF batteries. After the $50^{\text {th }}$ cycle, it increases to $10.2 \mathrm{k} \Omega$ for the NCM-KB, $8.8 \mathrm{k} \Omega$ for the NCM-SP, and $3.8 \mathrm{k} \Omega$ for NCM-VGCF batteries. This is in good agreement with the fact that the NCM-VGCF cathodes have the smallest side reaction, leading to the least resistive layers covered on the surface of electronic additives.

Furthermore, Fig. 3(d) shows the EIS of the batteries composed of NCM-based cathodes excluding electronic additives and the equivalent circuit of NCM-based solid state batteries, which can be deconvoluted to three major parts: the resistance of the LLZTO ceramic $\left(R_{0}\right)$, the in
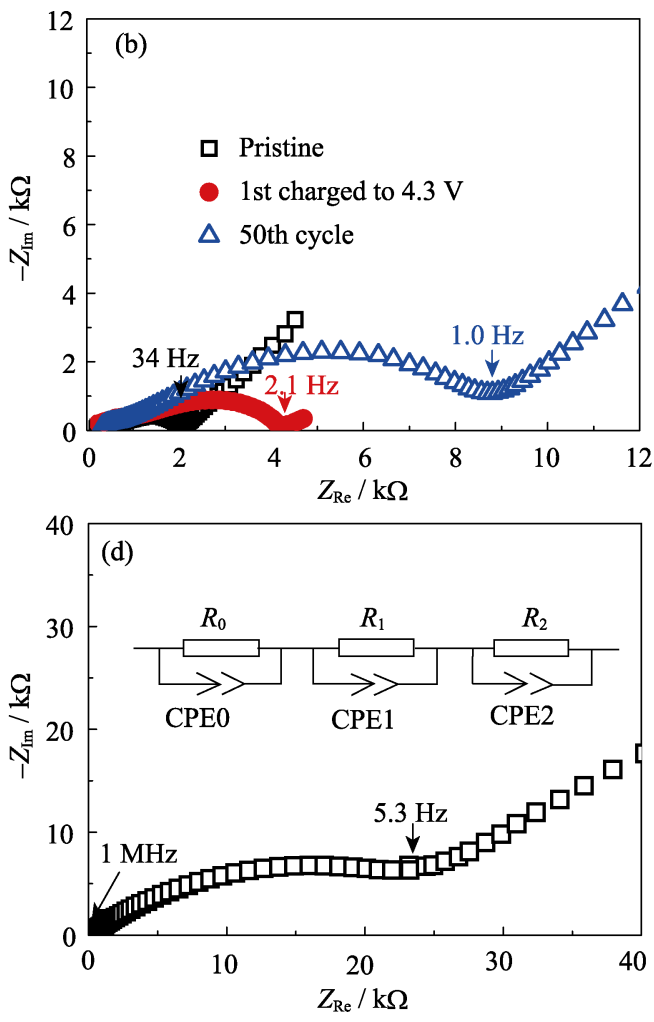

Fig. 3 EIS of NCM-based cathode/LLZTO/Li batteries with various carbon additives at different states with respect to (a) NCM-KB, (b) NCM-SP, (c) NCM-VGCF, and (d) excluding electronic additives 
terfacial resistance between LLZTO and $\mathrm{Li}$ anode $\left(R_{1}\right)$, and the interfacial resistance between LLZTO and NCMbased cathode $\left(R_{2}\right)$. The total internal resistance is over $20 \mathrm{k} \Omega$, which is 10 times larger than those including electronic additives $(\sim 2 \mathrm{k} \Omega)$, leading to the rather small capacity in Fig. 2(a). On basis of above discussion, it is clearly indicated that the internal resistance of the tested solid state batteries play critical role in available discharge capacity and cycle performance.

\subsection{Electrochemical stability of carbon elec- trodes on solid state batteries}

In order to get insight on the mechanism of different influence imposed by the various electronic additives, three-kind carbon electrodes excluding NCM were prepared and their properties of electrochemical stability at the high voltage range were investigated by LSV and Galvanostatic charge methods. Fig. 4(a) demonstrates the LSV profiles of three-kind carbon electrodes (C:PVdF: LiTFSI) with the same configuration of carbon electrode/ LLZTO/Li. It can be seen that for the SP and the VGCF, the onset of oxidation current occurs at ca. $4.1 \mathrm{~V}$. While for the $\mathrm{KB}$, the onset of oxidation current arises at the voltage of $3.6 \mathrm{~V}$. In addition, the current density at $4.3 \mathrm{~V}$ is the largest for the $\mathrm{KB}$ and the smallest for the VGCF. It is indicated that the KB has less crystallinity, far larger specific surface areas which means a larger amount of defects than the SP and VGCF (Fig. S2). On one hand, the carbon itself is apt to be oxidized at the increased voltage. On the other hand, the surface defects may promote decomposition of the LiTFSI. Both factors lower the electrochemical window of the carbon electrodes.

The $1^{\text {st }}$ charge curves of three-kind carbon electrodes with the same cell configuration at $40 \mu \mathrm{A} / \mathrm{mg}_{\mathrm{c}}(\sim 10 \mu \mathrm{A})$ are shown in Fig. 4(b). In accord with LSV, they become decomposed at various voltages and thus show charge capacities. For the $\mathrm{KB}$, the $1^{\text {st }}$ charge capacity reaches as large as $500 \mathrm{mAh} / \mathrm{g}_{\mathrm{c}}$ when being charged to $4.3 \mathrm{~V}$. This value is approximately 5 times larger than that for the SP and 20 times larger than that for the VGCF. This indicates that the electronic additives with the larger surface defects show the larger initial charge capacity. The VGCF with the smallest specific surface area and smallest amount of surface defects has the side reaction in the smallest degree.

To disclose the component of the resistive layers formed by the side reactions covered on the carbon surfaces, three-kind carbon electrodes were analyzed with XPS. Fig. 4(c) and 4(d) show C1s spectra of the pristine electrode materials and those after the $1^{\text {st }}$ charge, respectively. The C1s spectrum of the pristine electrode includes one main peak at binding energy of $284.9 \mathrm{eV}$, which can be attributed to the typical carbon materials
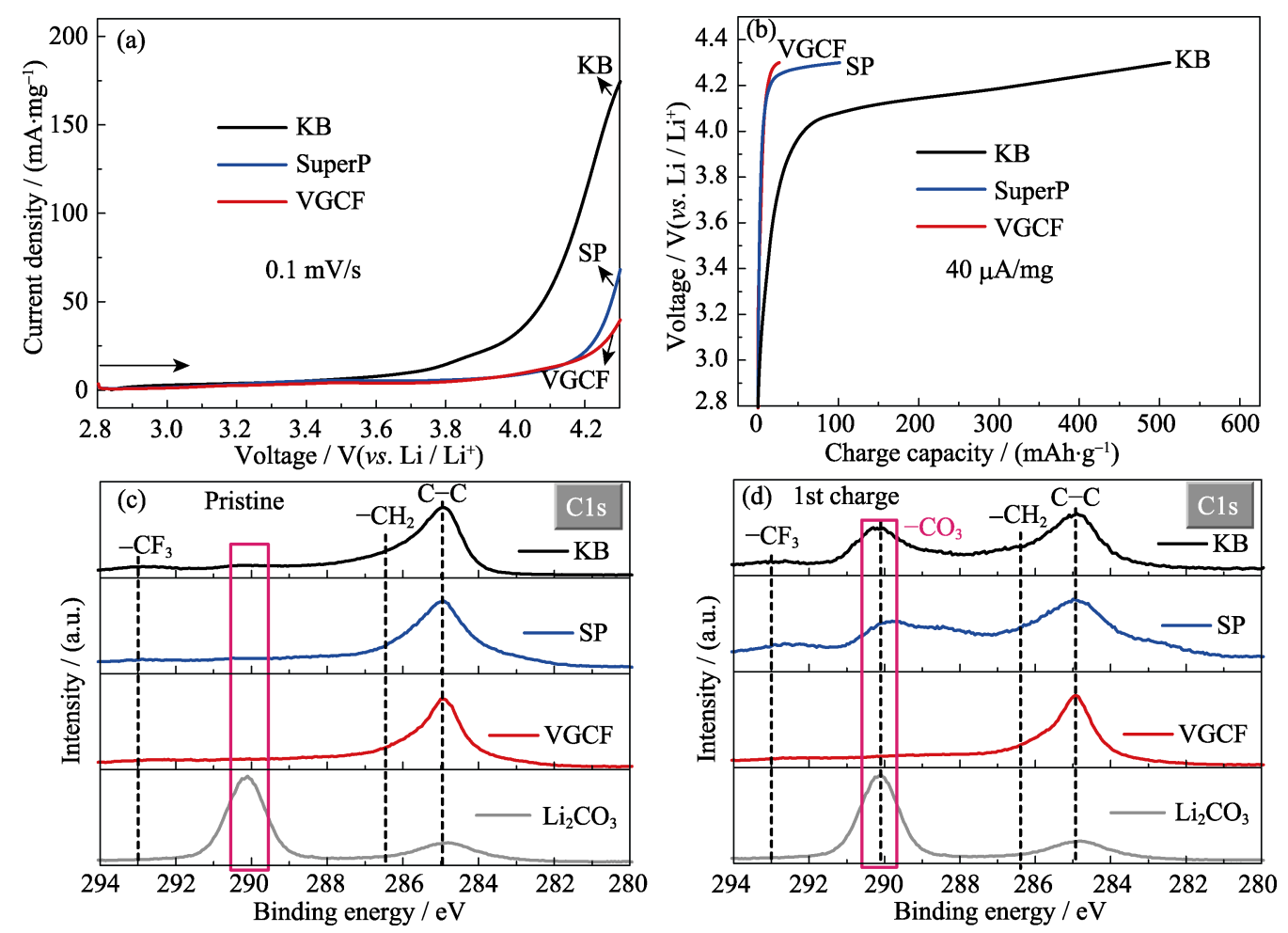

Fig. 4 (a) LSV of the carbon electrode/LLZTO/Li cells with KB, SP and VGCF as the component at the scan rate of $0.1 \mathrm{mV} / \mathrm{s}$; (b) The $1^{\text {st }}$ charge profile of the carbon electrode/LLZTO/Li cells for different components at $40 \mu \mathrm{A} / \mathrm{mg}_{c}$; (c, d) XPS of C1s spectra of the pristine samples and the $1^{\text {st }}$ charged products for the three-kind carbon electrodes, respectively. Carbon electrodes consist of C:LiTFSI:PVdF, and the current density and charge capacity are relative to the mass of carbon materials 
including KB, SP or VGCF ${ }^{[27]}$. Two small peaks at binding energies of $286.5 \mathrm{eV}$ and $293 \mathrm{eV}$ are attributed to $\mathrm{CH}_{2}$ from $\mathrm{PVdF}$ and $\mathrm{CF}_{3}$ from LiTFSI, respectively ${ }^{[28-29]}$. After the $1^{\text {st }}$ charging to $4.3 \mathrm{~V}$, the $290 \mathrm{eV}$ peak characterized of $\mathrm{CO}_{3}$ that is closely related to lithium carbonate increases significantly for the KB and the SP electrodes $^{[27-29]}$. It however has nearly no change for the VGCF electrodes. These results indicate that the carbonate is formed on the surface of carbon additives, most probably attributed to oxidation of defects existing on carbon surfaces and decomposition of the LiTFSI at the high voltage $^{[27,30]}$. Formation of the resistive carbonate results in the increase of impedance. For the NCM- VGCF-based batteries, less carbonates are formed compared to the NCM-KB and the NCM-SP-based solid state batteries, leading to the larger capacity retention and the smaller increase of internal resistance as shown in Fig. 2 and Fig. 3.

\section{Conclusions}

Cycle performance of the solid state lithium batteries with the lithium metal anodes, the LLZTO ceramic electrolytes, and the NCM-based composite cathodes has been investigated. It is clearly indicated that the carbons used as the electronic additives play an important role in the cycle performance. The KB carbons with larger specific surface area as well as larger amount of surface defects lead to more side reactions than the VGCF carbons. XPS analysis further reveals that the resistive carbonates are formed on the carbon surface due to the reactions between the oxidized surface defects of carbons and the decomposed LiTFSI at the high voltage range. Therefore, careful selection of electronic as well as ionic conducting additives is essential for construction of highly conducting and sustainable interfaces in the solid state lithium batteries with the NCM-based cathodes. More efforts on performance improvement of solid state batteries are being underway in our lab.

\section{References}

[1] YAO XIA-YIN, LIU DENG, WANG CHUN-SHENG, et al. High-energy all-solid-state lithium batteries with ultralong cycle life. Nano Letters, 2016, 16(11): 7148-7154.

[2] XU XIAO-XIONG, WEN ZHAO-YIN. Glass and glass-ceramics solid electrolytes for lithium-ion battery. Journal of Inorganic Materials, 2005, 20(1): 21-26.

[3] ZHANG JIAN-JUN, ZHAO JIANG-HUI, YUE LI-PING, et al. Safety-reinforced poly(propylene carbonate)-based all-solid-state polymer electrolyte for ambient-temperature solid polymer lithium batteries. Advanced Energy Materials, 2015, 5(24): 1401408.

[4] ZENG XIAN-XIANG, YIN YA-XIA, LI NIAN-WU, et al. Reshaping lithium plating/stripping behavior via bifunctional polymer electrolyte for room-temperature solid Li metal batteries. Journal of the American Chemical Society, 2016, 138(49): 15825-
15828.

[5] ZHENG YUE-LEI, CHEN REN-JIE, WU FENG, et al. Progress of research on the conductive mechanism of the glassy electrolytes in lithium ion batteries. Journal of Inorganic Materials, 2013, 28(11): 1172-1180.

[6] YADA CHIHIRO, OHMORI AKIHIRO, IDE KAZUTO, et al. Dielectric modification of $5 \mathrm{~V}$-class cathodes for high-voltaget all-solid-state lithium batteries. Advanced Energy Materials, 2014, 4(9): 1301416.

[7] MURUGAN RAMASWAMY, THANGADURAI VENKATARAMAN, WEPPNER WERNER. Fast lithium ion conduction in garnet-type $\mathrm{Li}_{7} \mathrm{La}_{3} \mathrm{Zr}_{2} \mathrm{O}_{12}$. Angewandte Chemie-International Edition, 2007, 46(41): 7778-7781.

[8] LIU CAI, WEN ZHAO-YIN, RUI KUN. High ion conductivity in garnet-type $\mathrm{F}$-doped $\mathrm{Li}_{7} \mathrm{La}_{3} \mathrm{Zr}_{2} \mathrm{O}_{12}$. Journal of Inorganic Materials, 2015, 30(9): 995-1000.

[9] HUANG MIAN, SHOJI MAO, SHEN YANG, et al. Preparation and electrochemical properties of $\mathrm{Zr}$-site substituted $\mathrm{Li}_{7} \mathrm{La}_{3}\left(\mathrm{Zr}_{2-x} \mathrm{M}_{x}\right) \mathrm{O}_{12}$ ( $M=\mathrm{Ta}, \mathrm{Nb})$ solid electrolytes. Journal of Power Sources, 2014, 261: 206-211.

[10] WU JIAN-FANG, CHEN EN-YI, YU YAO, et al. Gallium-doped $\mathrm{Li}_{7} \mathrm{La}_{3} \mathrm{Zr}_{2} \mathrm{O}_{12}$ garnet-type electrolytes with high lithium-ion conductivity. ACS Applied Materials \& Interfaces, 2017, 9(2): 1542-1552.

[11] TSAI CHIH-LONG, RODDATIS VLADIMIR, CHANDRAN C VINOD, et al. $\mathrm{Li}_{7} \mathrm{La}_{3} \mathrm{Zr}_{2} \mathrm{O}_{12}$ interface modification for Li dendrite prevention. ACS Applied Materials \& Interfaces, 2016, 8(16): 10617-10626.

[12] YAO XIA-YIN, HUANG BING-XIN, YIN JING-YUN, et al. All-solid-state lithium batteries with inorganic solid electrolytes: review of fundamental science. Chinese Physics B, 2016, 25(1): 018802.

[13] LUO WEI, GONG YUN-HUI, ZHU YI-ZHOU, et al. Transition from superlithiophobicity to superlithiophilicity of garnet solidstate electrolyte. Journal of the American Chemical Society, 2016, 138(37): 12258-12262.

[14] CHENG LEI, CHEN WEI, KUNZ MARTIN, et al. Effect of surface microstructure on electrochemical performance of garnet solid electrolytes. ACS Applied Materials \& Interfaces, 2015, 7(3): 2073-2081.

[15] HAN XIAO-GANG, GONG YUN-HUI, FU KUN (KELVIN), et al. Negating interfacial impedance in garnet-based solid-state Li metal batteries. Nature Materials, 2016, 16(5): 572.

[16] OHTA SHINGO, KOMAGATA SHOGO, SEKI JUNTARO, et al. All-solid-state lithium ion battery using garnet-type oxide and $\mathrm{Li}_{3} \mathrm{BO}_{3}$ solid electrolytes fabricated by screen-printing. Journal of Power Sources, 2013, 238: 53-56.

[17] OHTA SHINGO, SEKI JUNTARO, YAGI YUSUKE, et al. Co-sinterable lithium garnet-type oxide electrolyte with cathode for all-solid-state lithium ion battery. Journal of Power Sources, 2014, 265: 40-44.

[18] LIU TING, REN YAO-YU, SHEN YANG, et al. Achieving high capacity in bulk-type solid-state lithium ion battery based on $\mathrm{Li}_{6.75} \mathrm{La}_{3} \mathrm{Zr}_{1.75} \mathrm{Ta}_{0.25} \mathrm{O}_{12}$ electrolyte: interfacial resistance. Journal of Power Sources, 2016, 324: 349-357.

[19] KIM KI-HYUN, IRIYAMA YASUTOSHI, YAMAMOTO KAZUO, et al. Characterization of the interface between $\mathrm{LiCoO}_{2}$ and $\mathrm{Li}_{7} \mathrm{La}_{3} \mathrm{Zr}_{2} \mathrm{O}_{12}$ in an all-solid-state rechargeable lithium battery. Journal of Power Sources, 2011, 196(2): 764-767.

[20] PARK KYUSUNG, YU BYEONG-CHUL, JUNG JI-WON, et al. Electrochemical nature of the cathode interface for a solid-state lithium-ion battery: interface between $\mathrm{LiCoO}_{2}$ and garnet- 
$\mathrm{Li}_{7} \mathrm{La}_{3} \mathrm{Zr}_{2} \mathrm{O}_{12}$. Chemistry of Materials, 2016, 28(21): 8051-8059.

[21] VAN DEN BROEK JAN, AFYON SEMIH, RUPP JENNIFER L M. Interface-engineered all-solid-state Li-ion batteries based on garnet-type fast $\mathrm{Li}^{+}$conductors. Advanced Energy Materials, 2016, 6(19): 1600736.

[22] DU FU-MING, ZHAO NING, LI YI-QIU, et al. All solid state lithium batteries based on lamellar garnet-type ceramic electrolytes. Journal of Power Sources, 2015, 300: 24-28.

[23] OKADA KAZUYA, MACHIDA NOBUYA, NAITO MUNEYUKI, et al. Preparation and electrochemical properties of $\mathrm{LiAlO}_{2}$-coated $\mathrm{Li}\left(\mathrm{Ni}_{1 / 3} \mathrm{Mn}_{1 / 3} \mathrm{Co}_{1 / 3}\right) \mathrm{O}_{2}$ for all-solid-state batteries. Solid State Ionics, 2014, 255: 120-127.

[24] SAKUDA ATSUSHI, TAKEUCHI TOMONARI, KOBAYASHI HIRONORI. Electrode morphology in all-solid-state lithium secondary batteries consisting of $\mathrm{LiNi}_{1 / 3} \mathrm{Mn}_{1 / 3} \mathrm{Co}_{1 / 3} \mathrm{O}_{2}$ and $\mathrm{Li}_{2} \mathrm{~S}-\mathrm{P}_{2} \mathrm{~S}_{5}$ solid electrolytes. Solid State Ionics, 2016, 285: 112-117.

[25] HAN FU-DONG, ZHU YI-ZHOU Z, HE XING-FENG, et al. Electrochemical stability of $\mathrm{Li}_{10} \mathrm{GeP}_{2} \mathrm{~S}_{12}$ and $\mathrm{Li}_{7} \mathrm{La}_{3} \mathrm{Zr}_{2} \mathrm{O}_{12}$ solid electrolytes. Advanced Energy Materials, 2016, 6(8): 1501590.
[26] JALEM R, MORISHITA Y, OKAJIMA T, et al. Experimental and first-principles DFT study on the electrochemical reactivity of garnet-type solid electrolytes with carbon. Journal of Materials Chemistry A, 2016, 4(37): 14371-14379.

[27] YOUNESI REZA, CHRISTIANSEN ANE-SÆLLAND, SCIPIONI ROBERTO, et al. Analysis of the interphase on carbon black formed in high voltage batteries. Journal of the Electrochemical Society, 2015, 162(7): A1289-A1296.

[28] QUINLAN RONALD A, LU YI-CHUN, YANG SHAO-HORN, et al. XPS studies of surface chemistry changes of $\mathrm{LiNi}_{0.5} \mathrm{Mn}_{0.5} \mathrm{O}_{2}$ electrodes during high-voltage cycling. Journal of the Electrochemical Society, 2013, 160(4): A669-A677.

[29] YOUNESI REZA, HAHLIN MARIA, ROBERTS MATTHEW, et al. The SEI layer formed on lithium metal in the presence of oxygen: a seldom considered component in the development of the $\mathrm{Li}-\mathrm{O}_{2}$ battery. Journal of Power Sources, 2013, 225: 40-45.

[30] ZHENG JIAN-MING, XIAO JIE, XU WU, et al. Surface and structural stabilities of carbon additives in high voltage lithium ion batteries. Journal of Power Sources, 2013, 227: 211-217.

\title{
电子导电剂对石榴石基固态锂电池循环性能的影响
}

\author{
杜付明 ${ }^{1,2}$, 赵 宁 $^{3}$, 方 锐 ${ }^{1,2}$, 崔忠慧 ${ }^{1}$, 李忆秋 ${ }^{1}$, 郭向欣 ${ }^{1}$
}

(1. 中国科学院 上海硅酸盐研究所, 高性能陶瓷和超微结构国家重点实验室, 上海 200050; 2. 中国科学院大学, 北京 100049; 3. 青岛大学 物理学院, 青岛 266071)

摘 要: 基于石榴石固体电解质的固态锂电池面临着固体电解质和固体电极之间较大的界面阻抗问题, 导致循环性 能不佳。为了解决此问题, 本课题组制备并研究了 $\mathrm{LiNi}_{1 / 3} \mathrm{Co}_{1 / 3} \mathrm{Mn}_{1 / 3} \mathrm{O}_{2}$ 基正极、 $\mathrm{Li}_{6.4} \mathrm{La}_{3} \mathrm{Zr}_{1.4} \mathrm{Ta}_{0.6} \mathrm{O}_{12}$ 陶瓷固体电解质 和金属锂负极构成的固态锂电池。在构筑 $\mathrm{LiNi}_{1 / 3} \mathrm{Co}_{1 / 3} \mathrm{Mn}_{1 / 3} \mathrm{O}_{2}$ 基正极时采用三种不同的导电碳, 研究表明, 与科琴黑 和超导炭黑相比, 使用气相生长碳纤维(Vapor Grown Carbon Fiber, VGCF)时, 固态电池有更优异的循环性能。这是因 为充电到高电压时, VGCF 比另外两种导电剂引起的副反应更少, 从而减少能增加电池内阻的碳酸盐类副产物的形 成。这些结果说明电子导电剂的稳定性对固态锂电池的循环性能有重要影响。

关 键 词: 固态锂电池; 界面阻抗; 石榴石型电解质; 锂负极; 复合正极

中图分类号: TQ174 文献标识码: A 
Supporting Information:

\title{
Influence of Electronic Conducting Additives on Cycle Performance of Garnet-based Solid Lithium Batteries
}

\author{
DU Fu-Ming ${ }^{1,2}$, ZHAO Ning ${ }^{3}$, FANG Rui ${ }^{1,2}$, CUI Zhong-Hui ${ }^{1}$, LI Yi-Qiu ${ }^{1}$, GUO Xiang-Xin ${ }^{1}$ \\ (1. State Key Laboratory of High Performance Ceramics and Superfine Microstructure, Shanghai Institute of Ceramics, Chinese \\ Academy of Sciences, Shanghai 200050, China; 2. University of Chinese Academy of Sciences, Beijing 100049, China; 3. \\ College of Physics, Qingdao University, Qingdao 266071, China)
}

Electrochemical test of solid lithium batteries excluding ionic additives (LiTFSI) and liquid lithium ion batteries: $\mathrm{LiNi}_{1 / 3} \mathrm{Co}_{1 / 3} \mathrm{Mn}_{1 / 3} \mathrm{O}_{2}$ (NCM) cathodes were composed of $80 \mathrm{wt} \%$ NCM, 10wt\% PVdF, and $10 \%$ Super P, which were prepared by mixing NCM cathodes and $N$-methyl-2 pyrrolidon (NMP) in an agate mortar and ground for $1 \mathrm{~h}$. The obtained slurries were coated on one side of LLZTO ceramic plates or on the Al foil by blades, then dried in an oven at $80^{\circ} \mathrm{C}$ for $2 \mathrm{~h}$ to remove NMP. After being pressed with stainless-steel plate, the cathodes were dried in a vacuum oven at $80^{\circ} \mathrm{C}$ again for $12 \mathrm{~h}$ to remove the trace amount of NMP and moisture. The typical mass of each cathode was $2 \mathrm{mg} / \mathrm{cm}^{2}$. For solid lithium batteries, $\mathrm{Li}$ anode was attached on the other side of each LLZTO by high pressure, and then Swagelok-type batteries NCM/LLZTO/Li were assembled. While for liquid lithium ion batteries, Swagelok-type batteries were assembled with the NCM cathode, lithium anode, and $1 \mathrm{~mol} / \mathrm{L} \mathrm{LiPF} 6$ in ethylene carbonate (EC)/diethyl carbonate (DEC)/dimethyl carbonate (DMC) (1:1:1 in volume) electrolyte, and Celgard polypropylene separator. Electrochemical performance were investigated using an Arbin BT-2000 battery tester with the potential ranging from $4.3 \mathrm{~V}$ to $2.8 \mathrm{~V}$ at $60^{\circ} \mathrm{C}$ and $0.1 C$ (1C being $150 \mathrm{~mA} / \mathrm{g}$ ).

Fig. S1 compare the $1^{\text {st }}$ charge and discharge profiles of solid lithium batteries excluding ionic additives and liquid lithium ion batteries at $60^{\circ} \mathrm{C}$ and $0.1 C$, the discharge capacity is $0.4 \mathrm{mAh} / \mathrm{g}$ and $133 \mathrm{mAh} / \mathrm{g}$, respectively.
The huge difference comes from the absence of ionic additives in NCM cathode-based solid lithium batteries, while for liquid lithium ion batteries, liquid electrolytes ( $\mathrm{LiPF}_{6}$ solution) can easily infiltrate into the porous NCM cathode, providing effective and high $\mathrm{Li}^{+}$conducting channel both inside the cathode and at the interface between cathode and electrolyte.

Characterization of different carbon additives: Surface area of three carbon additives, including Ketejen black (KB), Super P (SP) and Vapor grown carbon fiber (VGCF), were analyzed by Brunauer-EMmett-Teller (BET) methods using a QUADRASORB SI system. The degree of gratiphization of different carbon additives were characterized by an X-ray diffractometer (D2 Discover, Bruker) in the range of $10^{\circ}-80^{\circ}$ at a scan rate of $0.02 \%$ using $\mathrm{CuK} \alpha$ radiation. Raman spectroscopy was recorded on Thermo DXR with an excitation wavelength of $532 \mathrm{~nm}$. Surface morphologies of the carbon additives were tested by scanning electron microscopy (SEM, SU8220)

Fig. S2(a) shows the XRD patterns of three carbon samples and the degree of graphitization can be distinguished. For KB and SP, only two broad (002) and (100) diffraction peaks exist, which stand for threedimension and two-dimension reflection peaks, respectively. Both they are considered as characteristic peaks of non-graphited carbon black ${ }^{[1]}$ while SP has relatively larger intensity for (002) peak. Two more diffraction peaks appear for VGCF, apart from sharper and larger (002)
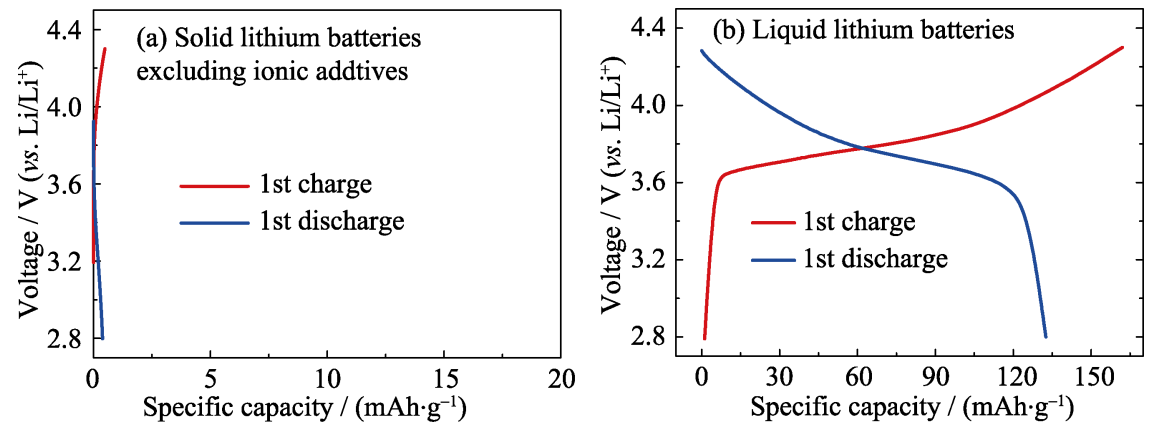

Fig. S1 The $1^{\text {st }}$ charge-discharge profiles of (a) solid lithium batteries with NCM composite cathode excluding ionic additives (b) NCM-based liquid lithium ion batteries, measured at $60^{\circ} \mathrm{C}$ and $0.1 \mathrm{C}$ 

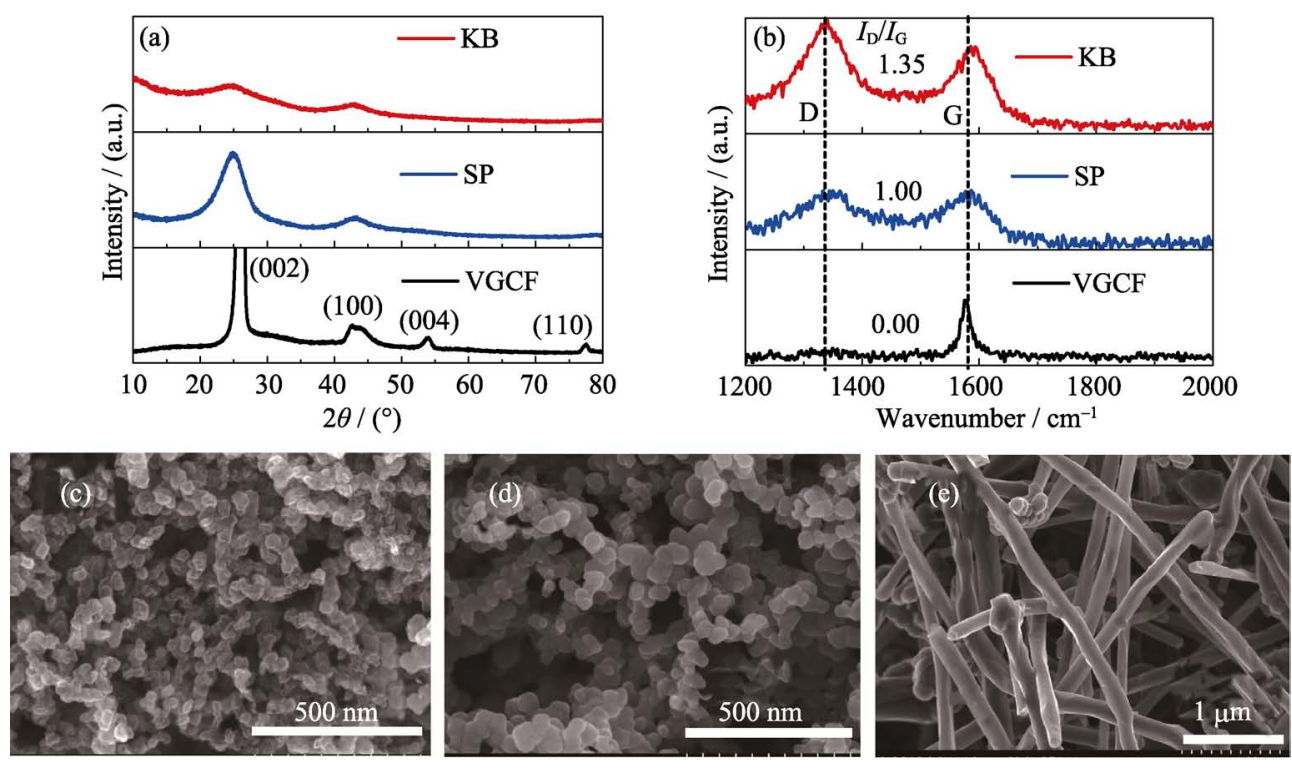

Fig. S2 (a) XRD Patterns, (b) Raman spectra, and (c-e) SEM images of KB, SP, and VGCF

peak (only shown part for the same scale): threedimension (004) and two dimension (110) peaks at $2 \theta=$ $54^{\circ}$ and $77^{\circ}$, respectively. The pattern of VGCF is very close to graphite and it has the highest crystal degree, which means less disorder. So, the graphitization degree is increased by the order: $\mathrm{KB}<\mathrm{SP}<\mathrm{VGCF}$.

Raman spectroscopy is always employed to study the defect density of carbon materials. Fig. S2(b) shows Raman bands of three carbon samples and the frequency of the $\mathrm{G}$ band is at about $1580 \mathrm{~cm}^{-1}$ and $\mathrm{D}$ band is at about $1340 \mathrm{~cm}^{-1[2]}$. The $\mathrm{G}$ band comes from the in-plane vibration of $\mathrm{sp}^{2}$ carbon $(\mathrm{C}=\mathrm{C})$, while $\mathrm{D}$ band is attributed to $\mathrm{sp}^{3}$ carbon $(\mathrm{C}-\mathrm{C})$ caused by disorders and defects. The decreased $I_{\mathrm{D}} / I_{\mathrm{G}}$ ratio $(1.35,1.00,0$ for $\mathrm{KB}, \mathrm{SP}, \mathrm{VGCF})$ manifests that the defect density is reduced by the order: KB > SP >> VGCF. Since there's no perfect crystal without defects, VGCF must have slight defects which almost can't be detected because of the restriction of the test condition.
Fig. S2(c)-(e) show the morphologies of three carbon samples. KB and SP has a powdery morphology with an average particle size of about 25 and $50 \mathrm{~nm}$, respectively, while VGCF has a pillar-like morphology with an average particle diameter and length of $\sim 150 \mathrm{~nm}$ and $\sim 8 \mu \mathrm{m}$, respectively. The specific surface areas of the three carbon samples decrease in the order of KB $\left(1149 \mathrm{~m}^{2} / \mathrm{g}\right)$ >> SP $\left(61 \mathrm{~m}^{2} / \mathrm{g}\right)>\operatorname{VGCF}\left(16 \mathrm{~m}^{2} / \mathrm{g}\right)$ according to the results of BET.

\section{References:}

[1] QI X, BLIZANAC B, DUPASQUIER A, et al. Influence of thermal treated carbon black conductive additive on the performance of high voltage spinel $\mathrm{Cr}$-doped $\mathrm{LiNi}_{0.5} \mathrm{Mn}_{1.5} \mathrm{O}_{4}$ composite cathode electrode. Journal of the Electrochemical Society, 2015, 162(3): A339-A343.

[2] ZHANG S, CUI Y H, WU B, et al. Control of graphitization degree and defects of carbon blacks through ball-milling. RSC Advances, 2014, 4(1): 505-509. 